\title{
A bivalent promoter contributes to stress-induced plasticity of CXCR4 in Ewing sarcoma
}

\author{
Melanie A. Krook ${ }^{1,2}$, Allegra G. Hawkins ${ }^{1,2}$, Rajiv M. Patel ${ }^{3}$, David R. Lucas ${ }^{3}$, \\ Raelene Van Noord ${ }^{1,2}$, Rashmi Chugh ${ }^{4}$, Elizabeth R. Lawlor ${ }^{1,2,3}$ \\ ${ }^{1}$ Translational Oncology Program, University of Michigan, Ann Arbor, MI, USA \\ ${ }^{2}$ Department of Pediatrics and Communicable Diseases, University of Michigan, Ann Arbor, MI, USA \\ ${ }^{3}$ Department of Pathology, University of Michigan, Ann Arbor, MI, USA \\ ${ }^{4}$ Department of Internal Medicine, University of Michigan, Ann Arbor, MI, USA \\ Correspondence to: Elizabeth R. Lawlor, email: elawlor@umich.edu \\ Keywords: CXCR4, epigenetics, plasticity, Ewing sarcoma
}

Received: May 02, $2016 \quad$ Accepted: July 28, 2016

Published: August 12, 2016

\section{ABSTRACT}

Tumor heterogeneity is a major impediment to cancer cures. Tumor cell heterogeneity can arise by irreversible genetic mutation, as well as by non-mutational mechanisms, which can be reversibly modulated by the tumor microenvironment and the epigenome. We recently reported that the chemokine receptor CXCR4 is induced in Ewing sarcoma cells in response to microenvironmental stress. In the current study, we investigated plasticity of CXCR4 expression in vivo and assessed whether CXCR4 impacts on tumor growth. Our studies showed that Ewing sarcoma cells convert between CXCR4 negative and CXCR4 positive states in vivo and that positive cells are most abundant adjacent to areas of necrosis. In addition, tumor volumes directly correlated with CXCR4 expression supporting a role for CXCR4 in growth promotion. Mechanistically, our results show that, in ambient conditions where CXCR4 expression is low, the CXCR4 promoter exists in a poised, bivalent state with simultaneous enrichment of both activating (H3K4me3) and repressive (H3K27me3) post-translational histone modifications. In contrast, when exposed to stress, CXCR4 negative cells lose the $\mathrm{H} 3 \mathrm{~K} 27 \mathrm{me} 3$ mark. This loss of promoter bivalency is associated with CXCR4 upregulation. These studies demonstrate that stress-dependent plasticity of CXCR4 is, in part, mediated by epigenetic plasticity and a bivalent promoter.

\section{INTRODUCTION}

Tumor heterogeneity contributes to tumor progression and remains a major challenge in the treatment and diagnosis of cancer as well as for the development of novel cancer therapeutics $[1,2]$. Furthermore, although biological heterogeneity between tumor and non-tumor stroma is a major determinant of tumor behavior, it is increasingly evident that phenotypic heterogeneity among tumor cells themselves is also of profound importance to disease progression, therapy response and clinical outcomes. This phenotypic heterogeneity can include variability in gene expression, motility, and metastatic potential across cells in a tumor [3] and can be driven by both genetic and epigenetic mechanisms, as well as by contributions of the tumor microenvironment $[2,4]$.
The CXCL12-CXCR4 chemotactic axis contributes to metastasis of numerous different human cancers and CXCR4 positive tumor cells are often detected at the leading edge of invasive tumors and in cancer stem cell populations $[5,6]$. In light of this, the CXCL12-CXCR4 axis is of great therapeutic interest and pharmacologic approaches are being developed to target CXCR4 signaling as an anti-cancer strategy $[7,8]$. We recently showed that expression of CXCR4 is heterogeneous and dynamically regulated in Ewing sarcoma, an aggressive bone and soft tissue tumor that peaks in adolescents and young adults [9]. In particular, exposure of tumor cells to microenvironmental stress, including growth factor deprivation, hypoxia, and physical growth constraints resulted in upregulation of CXCR4, either at the level of mRNA or cell surface protein expression, or both [9]. This 
upregulation of CXCR4 was associated with phenotypic transition of Ewing sarcoma cells from relatively nonmotile states to cells that actively migrated and invaded towards the CXCL12 ligand [9]. Previously, expression of CXCR4 transcript was found to be increased in tumor biopsies from patients with metastatic Ewing sarcoma compared to localized tumors, suggesting that CXCR4 signaling may contribute to tumor metastasis [10]. In addition, there is evidence that local growth of Ewing sarcomas is also promoted by CXCR4 pathway activation [11]. Thus, elucidation of the mechanisms underlying CXCR4 regulation in Ewing sarcoma could provide insights into the molecular mechanisms of Ewing sarcoma cell heterogeneity and tumor progression.

In the current study we assessed plasticity of CXCR4 in Ewing sarcoma tumor cells in vivo. In addition, we evaluated the chromatin state of the CXCR4 locus in a panel of Ewing sarcoma cell lines to determine if epigenetic plasticity contributes to stress-dependent activation of CXCR4. The findings from these studies demonstrate that Ewing sarcoma cells transition between CXCR4 negative and CXCR4 positive states in vivo, that this phenotypic heterogeneity contributes to tumor growth and is, at least in part, driven by epigenetic plasticity of the $C X C R 4$ promoter in response to microenvironmental stress.

\section{RESULTS}

\section{Ewing sarcoma cells transition between CXCR4 negative and CXCR4 positive states in vivo}

We previously showed that Ewing cells transition between CXCR4 positive and CXCR4 negative states in vitro and that $\mathrm{CXCR} 4$ is induced in response to stress [9]. In order to determine if similar phenotypic transitions occur in vivo we FACS-sorted TC-32 cells on the basis of CXCR4 (Figure 1A) and injected cells via tail vein into immunodeficient mice. qRT-PCR confirmed that levels of $C X C R 4$ transcript were substantially lower in the CXCR4 negative cells at the time of cell injection (Figure 1B). Bioluminescence imaging detected no significant difference in time to tumor engraftment between the two groups. After eight weeks, mice were euthanized and tumor numbers and volumes were determined. A total of 5 out of 8 mice developed tumors in the CXCR4- cell population and 8 out of 10 mice developed tumors that were injected with CXCR4 positive cells ( $p=0.6$, Fisher's exact test). Final tumor volumes were also equivalent between the groups at the time of necropsy, with a trend to increased volume in CXCR4 positive cell-derived tumors (Figure 1C). Examination of gene expression in the excised tumors revealed that $C X C R 4$ transcript levels in resected tumors directly correlated with tumor volume, suggesting that expression of CXCR4 in established tumors might promote tumor growth
(Figure 1D). Notably, however, mean CXCR4 transcript expression in tumors from both groups of recipient mice was equivalent at the time of resection (Figure 1E). Thus, these findings revealed that the CXCR4 state at the time of tumor cell injection was not a key determinant of CXCR4 expression at the time of tumor resection. Rather, the data suggested that all tumors evolved to a mixed population of CXCR4 positive and CXCR4 negative cells, resulting in a relative decrease in $C X C R 4$ expression in the CXCR4 positive cohort and an increase in $C X C R 4$ expression in the CXCR4 negative cohort. To address this possibility, excised tumors were assessed by immunohistochemistry to evaluate the presence of CXCR4 positive and negative tumors cells. Significantly, mixed populations of CXCR4 negative and CXCR4 positive cells were evident in all tumors regardless of their CXCR4 status at the time of injection. In particular, CXCR4 negative/CD99 positive tumor cells were present in abundance in tumors that arose from CXCR4 positive cells (Figure 2A). Conversely, CXCR4 positive/CD99 positive cells were readily detected in tumors that arose from strictly CXCR4 negative cell injections (Figure 2B). Notably, in both groups CXCR4+ cells were most abundant adjacent to areas of necrosis (Figure 2C \& 2D). These findings support our prior in vitro observations that Ewing sarcoma cells are highly plastic with respect to CXCR4 expression and that exposure to microenvironmental stress promotes acquisition of a CXCR4 positive cell phenotype.

\section{The $C X C R 4$ promoter is bivalent in Ewing sarcoma cells}

The results of the xenograft studies confirmed that CXCR4 expression is highly plastic in Ewing sarcoma cells in vivo and that transition of cells from CXCR4 negative to CXCR4 positive states is most prominently observed adjacent to areas of necrosis. Given the integral role of epigenetic deregulation in Ewing sarcoma pathogenesis, and our observations that the transition of CXCR4 negative cells into CXCR4 positive states is associated with changes in levels of $C X C R 4$ transcript, we investigated whether epigenetic plasticity contributes to stress-induced plasticity.

Multiple mechanisms contribute to epigenetic regulation of gene expression in normal and malignant development, including post-translational histone modifications at gene promoters [12]. In particular, rapid induction of gene expression in stem cells is achieved by the simultaneous presence of both activating ( $\mathrm{H} 3 \mathrm{~K} 4 \mathrm{me} 3$ ) and repressive ( $\mathrm{H} 3 \mathrm{~K} 27 \mathrm{me} 3)$ histone marks at key developmental gene promoters, creating loci that are silenced but poised for rapid activation in response to appropriate cues [13]. The significance of bivalent loci to gene activation in cancer was recently described in the context of breast cancer stem cells and epithelial-tomesenchymal transitions [14]. To begin to address whether 
bivalency might play a role in $\mathrm{CXCR} 4$ regulation we first asked whether the $C X C R 4$ locus is bivalent in embryonic stem cells, cells where bivalency was first described [13]. As shown, analysis of the ENCODE database [15] revealed that both $\mathrm{H} 3 \mathrm{~K} 27 \mathrm{me} 3$ and $\mathrm{H} 3 \mathrm{~K} 4 \mathrm{me} 3$ histone modifications are enriched at the $C X C R 4$ promoter in human embryonic stem cells, consistent with a bivalent state (Figure 3A, top). In contrast, in HeLa cells, the CXCR4 promoter is characterized by a univalent state, with enrichment of only the $\mathrm{H} 3 \mathrm{~K} 4 \mathrm{me} 3$ mark and complete absence of the repressive $\mathrm{H} 3 \mathrm{~K} 27 \mathrm{me} 3$ modification (Figure $3 \mathrm{~A}$, bottom). In Ewing sarcoma cell lines we have shown that CXCR4 expression is normally expressed by only a minority of cells under ambient conditions [9]. Conversely, most HeLa cells express high levels of CXCR4 on their cell surface (Figure 3B). To evaluate the chromatin state of the $C X C R 4$ promoter in Ewing sarcoma we performed ChIP-PCR studies using antibodies directed against the H3K4me3 and H3K27me3 histone modifications and genomic PCR primers specific for the CXCR4 promoter (Supplementary Figure S1A). These studies revealed that both the activating and repressive histone marks are highly enriched at the $C X C R 4$ promoter in all Ewing sarcoma cell lines, consistent with the identity of a bivalent locus (Figure 3C \& 3D and Supplementary Figure S1B). In contrast, we confirmed that only the active chromatin mark $\mathrm{H} 3 \mathrm{~K} 4 \mathrm{me} 3$ was detectable at the CXCR4 promoter in $\mathrm{HeLa}$ cells (Figure 3C \& 3D and Supplementary Figure S1B).
A

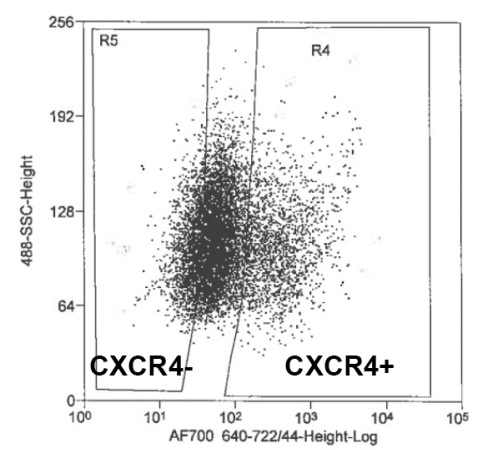

C

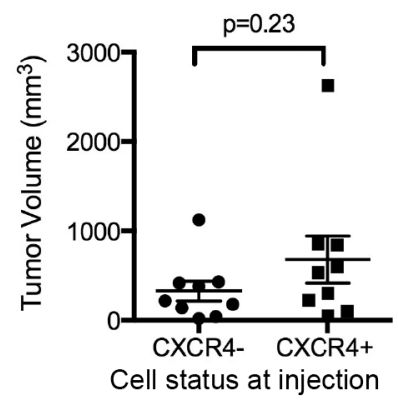

$\mathbf{E}$

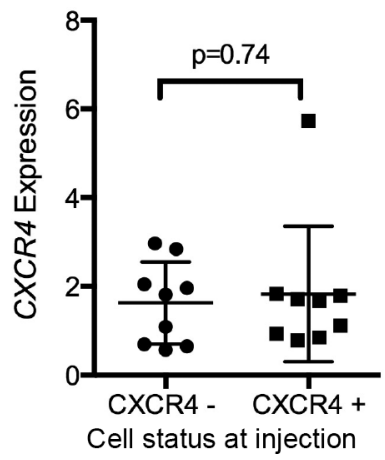

B

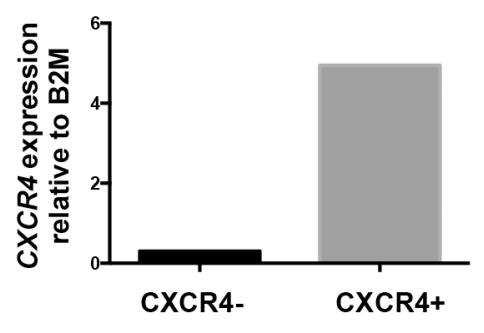

D

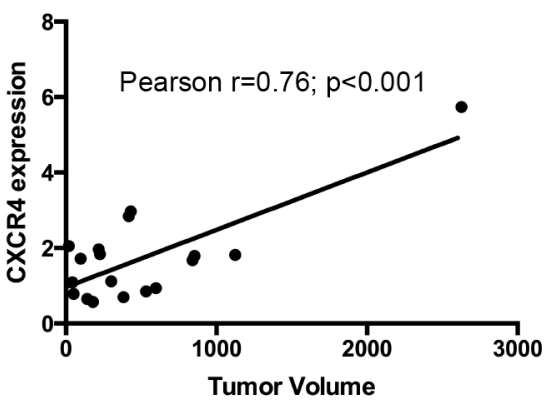

Figure 1: Ewing sarcoma cells transition between CXCR4 negative and positive states in vivo. A. FACS-sorting of TC-32 cells on the basis of cell surface CXCR4 prior to injection into tail veins of NOD-SCID mice. B. FACS-sorting generated cell populations with differential expression of CXCR4 transcript as determined by qRT-PCR. C. Tumors were excised at necropsy and volumes determined. Nine tumors were analyzed in each group (from 5 CXCR4 negative and 8 CXCR4 positive recipient mice). D. A direct correlation was observed between $C X C R 4$ expression, as determined by qRT-PCR, and tumor volume in excised tumors. E. CXCR4 expression in tumors at the time of necropsy as determined by qRT-PCR. Expression of $C X C R 4$ was highly variable. Mean expression was equivalent between the two groups. 
Relative enrichment of the $\mathrm{H} 3 \mathrm{~K} 4 \mathrm{me} 3$ modification was positively correlated $(\mathrm{r}=0.9630)$ with $C X C R 4$ expression in the tested cell lines while H3K27me3 was negatively correlated $(\mathrm{r}=-0.6929)$ with $C X C R 4$ transcript expression (Figure 3E).
Our finding that both modifications were enriched at the $C X C R 4$ promoter in independent ChIP studies was suggestive of, but not conclusive for, bivalency. To more definitively test for bivalency we went on to determine if the simultaneous presence of both marks could be
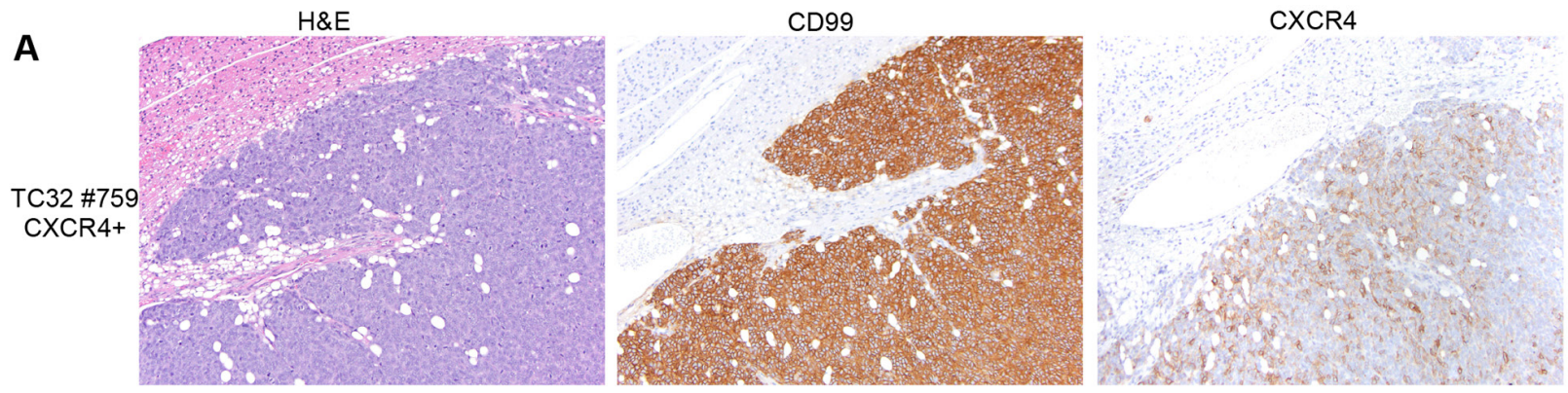

B $\quad$ H\&E

$H \& E$
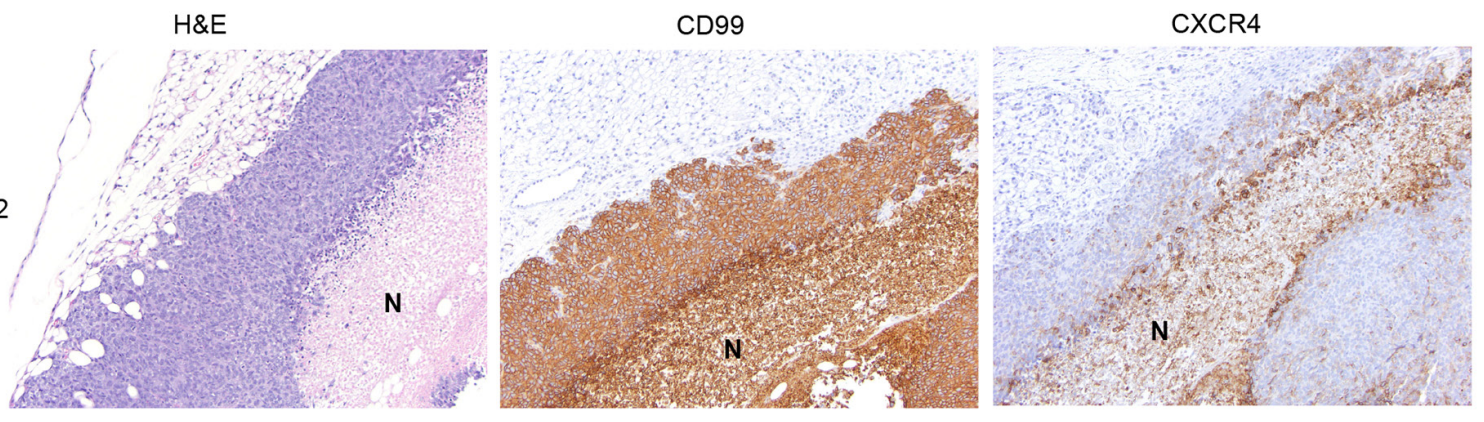

C
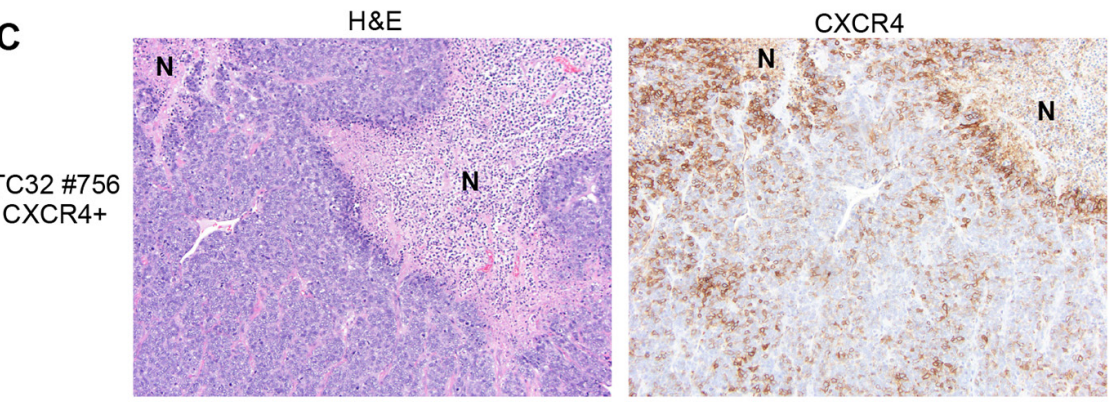

D

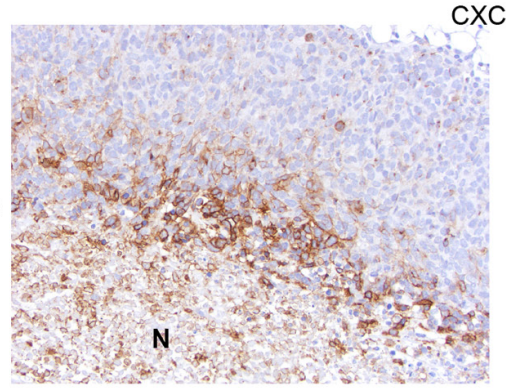

CXCR4

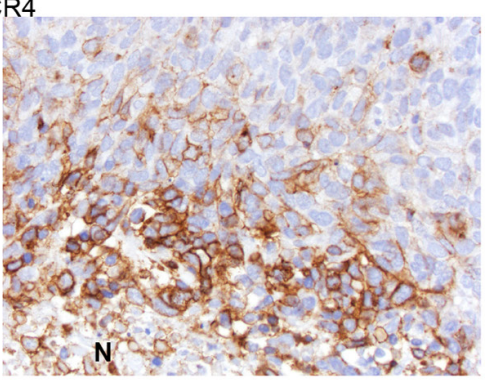

Figure 2: Heterogeneity of CXCR4 expression is evident in tumors irrespective of CXCR4 status at the time of injection. A. Immunostaining of xenograft tumor sections shows abundant CXCR4 negative tumor cells in tumors derived from CXCR4 positive cells. 10x images of a representative tumor. B. CXCR4 positive tumor cells are detected in tumors derived from CXCR4 negative cells. 10x images of a representative tumor. $\mathrm{N}=$ necrotic region. $\mathrm{C}$. $\mathrm{CXCR} 4$ positive cells are increased adjacent to areas of tumor necrosis. $10 \mathrm{x}$ images of a representative tumor derived from CXCR4 positive cells ( $\mathrm{N}=$ necrotic region). $\mathbf{D}$. High power images of CXCR4 negative cell-derived tumor as in B (left panel: 20x; right panel: 40x) show increased frequency of CXCR4 positive tumor cells immediately adjacent to areas of necrosis. 
detected in the same chromatin preparation by performing sequential ChIP experiments. As shown, these ChIPre-ChIP studies again revealed only the presence of the $\mathrm{H} 3 \mathrm{~K} 4 \mathrm{me} 3$ modification in HeLa cells, confirming its univalent chromatin state (Figure 4A). In Ewing sarcoma samples, $\mathrm{H} 3 \mathrm{~K} 4 \mathrm{me} 3$ was detected at the $C X C R 4$ promoter in chromatin that had been isolated by the $\mathrm{H} 3 \mathrm{~K} 27 \mathrm{me} 3-$ directed antibody (K27/K4) and vice versa (K4/K27) (Figure 4B). Thus, in ambient, unstressed conditions, the $C X C R 4$ promoter of Ewing sarcoma cells resides in a bivalent state and, as such, may be poised and ready for activation in response to microenvironmental cues.

A

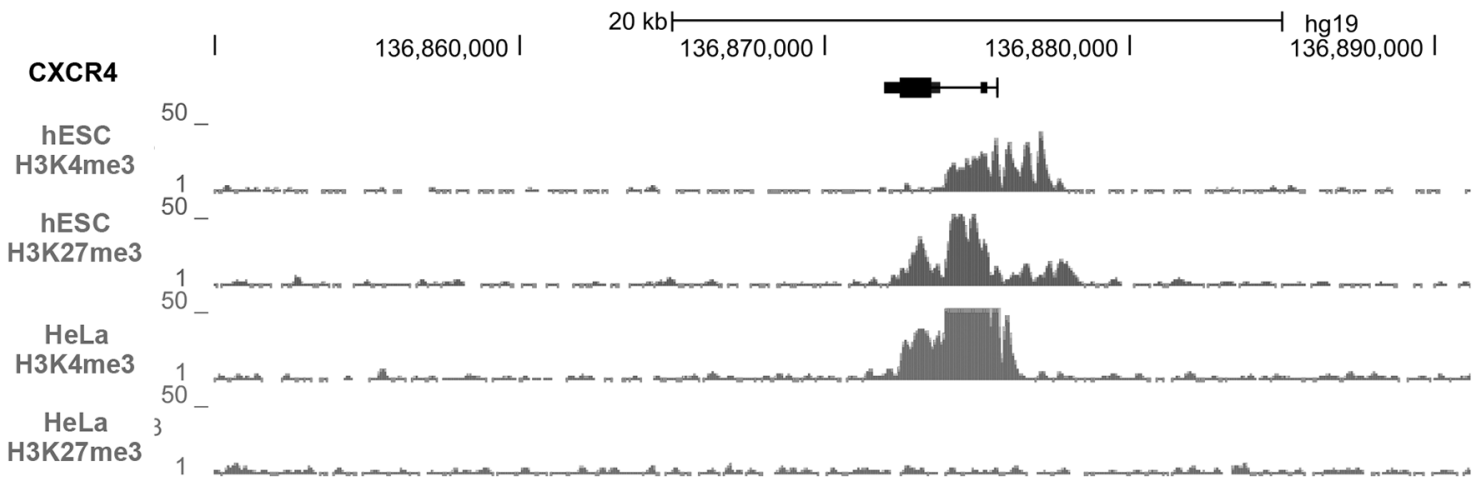

B

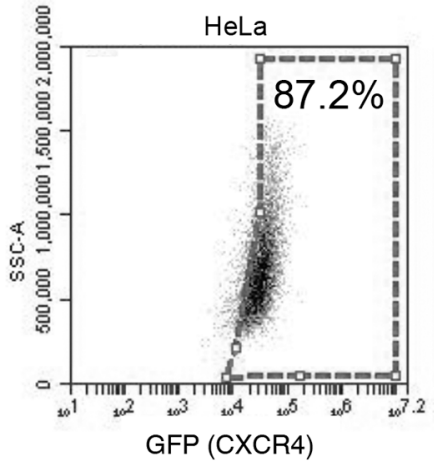

E

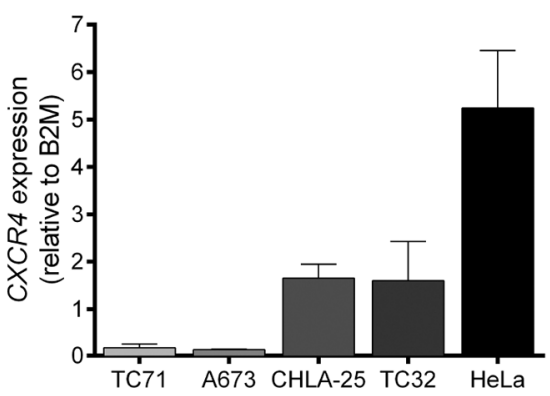

C

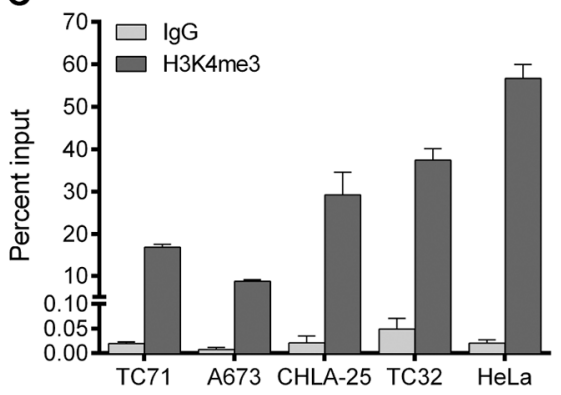

D

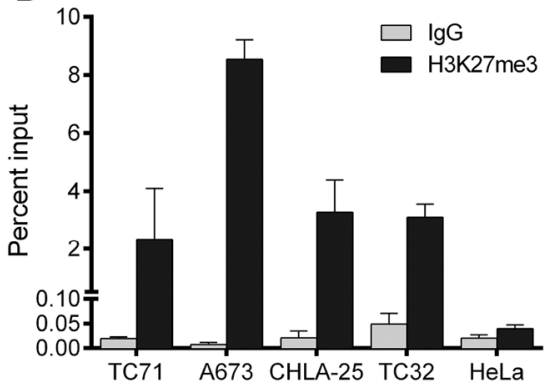

$\mathbf{F}$
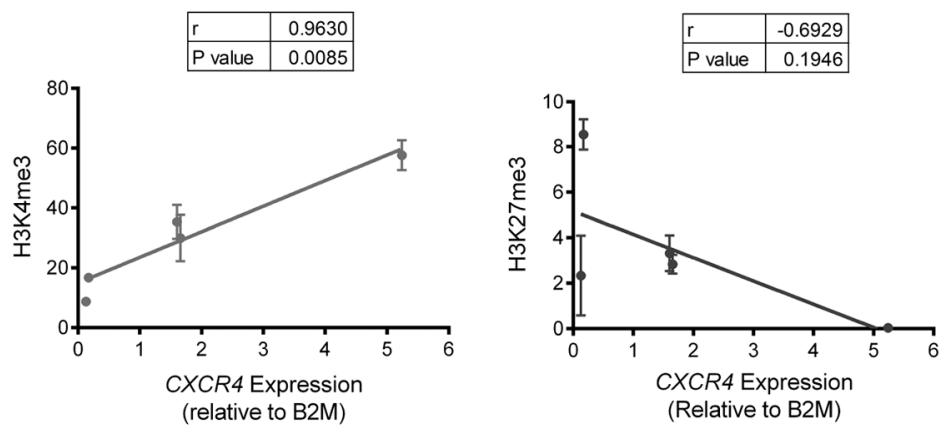

Figure 3: The CXCR4 promoter is enriched with both the H3K4me3 and H3K27me3 histone marks in Ewing sarcoma cells. A. Gene tracks for $\mathrm{H} 3 \mathrm{~K} 4 \mathrm{me} 3$ and $\mathrm{H} 3 \mathrm{~K} 27 \mathrm{me} 3$ at the $C X C R 4$ promoter in human embryonic stem cells (hESC) and HeLa cells assembled from the ENCODE database demonstrate a bivalent state in hESC cells and a univalent active state in HeLa cells. B. FACS analysis of HeLa cells shows that most cells express CXCR4. C. Targeted ChIP-qPCR studies showed that the H3K4me3 is enriched at the CXCR4 promoter in both Ewing sarcoma and in HeLa cells. D. Targeted ChIP-qPCR studies showed that the H3K27me3 modification is enriched at the CXCR4 promoter of Ewing sarcoma cells but is not present in HeLa cells. E. CXCR4 expression as determined in a panel of Ewing sarcoma cell lines and HeLa cells using qRT-PCR. Data represented as mean $\pm \mathrm{SEM}$ of three independent experiments. F. Expression of $C X C R 4$ correlates directly with enrichment of $\mathrm{H} 3 \mathrm{~K} 4 \mathrm{me} 3$ and inversely with $\mathrm{H} 3 \mathrm{~K} 27 \mathrm{me} 3$ at the $C X C R 4$ promoter. $\mathrm{r}=\mathrm{Pearson}$ correlation co-efficient. 


\section{Upregulation of CXCR4 expression is associated with loss of $\mathrm{H3K} 27 \mathrm{me} 3$}

Consistent with a poised, bivalent chromatin state, most Ewing sarcoma cells do not express high levels of CXCR4 [9]. However, we previously noted that two Ewing sarcoma cell lines, CHLA-25 and TC-32, exist in an equilibrium state wherein $30-40 \%$ of cells express high levels of CXCR4 transcript and protein [9]. We took advantage of the inherent heterogeneity of these two cell lines to directly address the contribution of the $\mathrm{H} 3 \mathrm{~K} 27 \mathrm{me} 3$ modification to $C X C R 4$ gene repression and H3K 4 me 3 modification to gene activation. CHLA-25 and TC-32 cells were FACS-sorted to isolate pure populations of CXCR4 negative and CXCR4 positive populations (Figure 5A). As expected, CXCR4 mRNA expression in these populations correlated with surface protein expression (Figure 5B). Moreover, analysis of histone modifications demonstrated preferential enrichment of H3K27me3 in the CXCR4 negative populations (Figure 5C) and $\mathrm{H} 3 \mathrm{~K} 4 \mathrm{me} 3$ in the CXCR4 high populations (Figure 5D), supporting a role for these modifications in gene regulation. The $\mathrm{H} 3 \mathrm{~K} 27 \mathrm{me} 3$ modification is mediated by the polycomb repressive complex protein EZH2, which functions as a histone methyltransferase and as a pro-tumorigenic oncogene in Ewing sarcoma [16]. To determine if the presence of $\mathrm{H} 3 \mathrm{~K} 27 \mathrm{me} 3$ directly mediates silencing of CXCR4 gene expression we exposed cells to GSK-126, a highly selective pharmacologic inhibitor of EZH2 methyltransferase activity [17]. Expression of CXCR4 increased in all Ewing sarcoma cell lines following exposure to GSK-126 (Figure 5E) and this was accompanied by loss of the H3K27me 3 modification (Figure 5F) but no change in $\mathrm{H} 3 \mathrm{~K} 4 \mathrm{me} 3$ enrichment at the CXCR4 promoter (Figure 5G). Thus, repression of CXCR4 expression in Ewing sarcoma is, at least in part, dependent on EZH2 and on the presence of the H3K27me3 modification at the gene promoter.

Finally, we evaluated whether changes in these histone modifications were evident in Ewing sarcoma cells that had been exposed to microenvironmental stress. Withdrawal of serum for 24 hours resulted in upregulated expression of CXCR4 in three of four cell lines (Figure 6A) and in all three cases this was reproducibly accompanied by loss of H3K27me3 at the gene promoter (Figure 6B). In contrast, no change in $\mathrm{H} 3 \mathrm{~K} 4 \mathrm{me} 3$ was observed (Figure $6 \mathrm{C})$. To further define the nature of cells that experienced loss of bivalency in the context of growth factor withdrawal, we FACS-sorted TC-32 cells on the basis of CXCR4 expression and exposed the sorted cells to either $10 \%$ serum or serum free media for 24 hours (Figure 6D). Interestingly, CXCR4 transcript expression was relatively increased
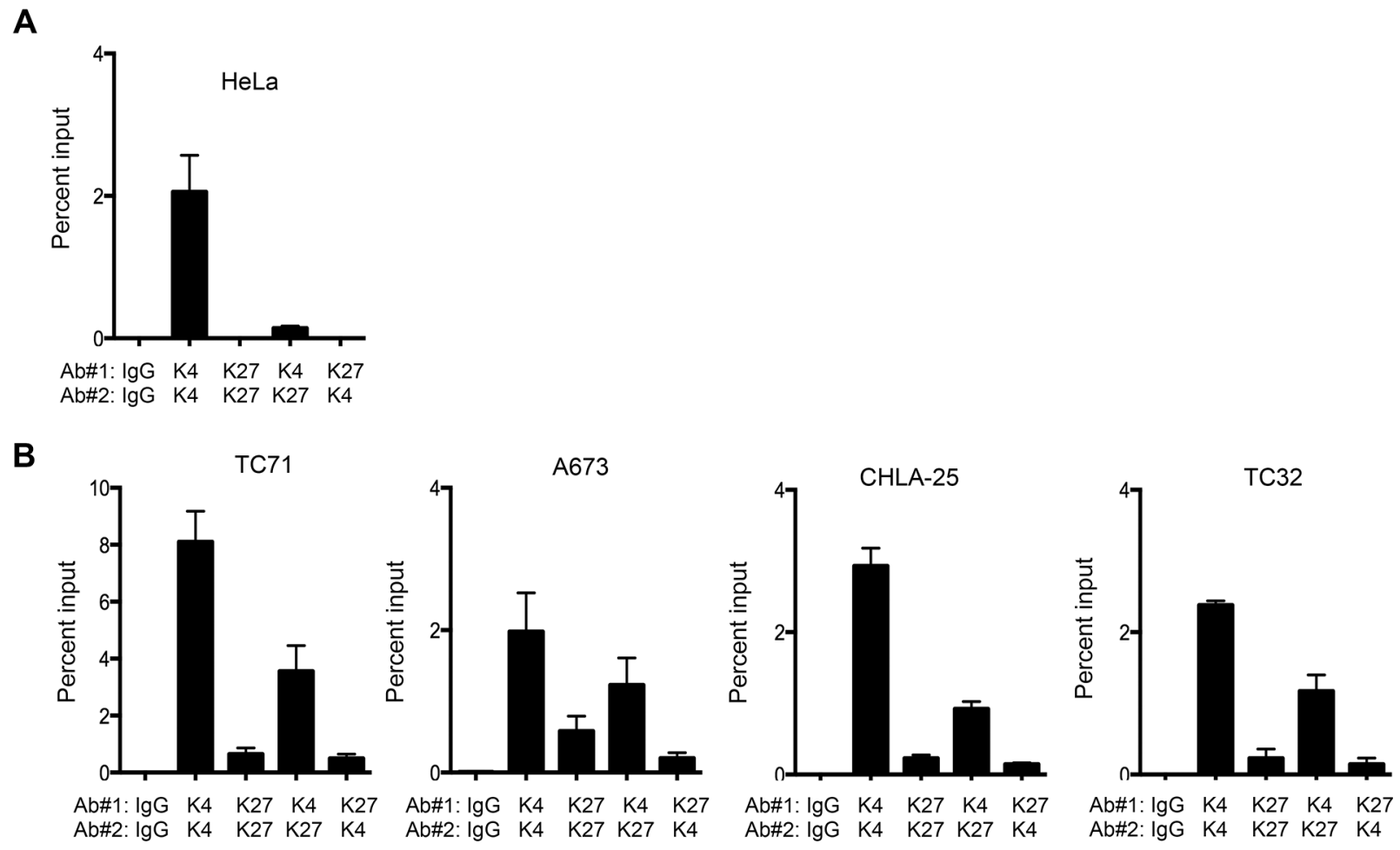

Figure 4: The CXCR4 promoter is bivalent in Ewing sarcoma cells. A. Sequential ChIP-qPCR experiments (ChIP-re-ChIP) for H3K4me3 followed by H3K27me3 (K4/K27) and vice versa (K27/K4), demonstrated only the H3K4me3 modification in HeLa cells, confirming its univalent chromatin state. B. ChIP-re-ChIP of Ewing sarcoma cells showed H3K4me3 at H3K27me3-marked chromatin (K4/K27), and vice versa (K27/K4) thus confirming that the $C X C R 4$ promoter is bivalent. IgG, K4/K4, and K27/K27 served as controls. Data represented as mean $\pm \mathrm{SEM}$ of three independent experiments. 
A

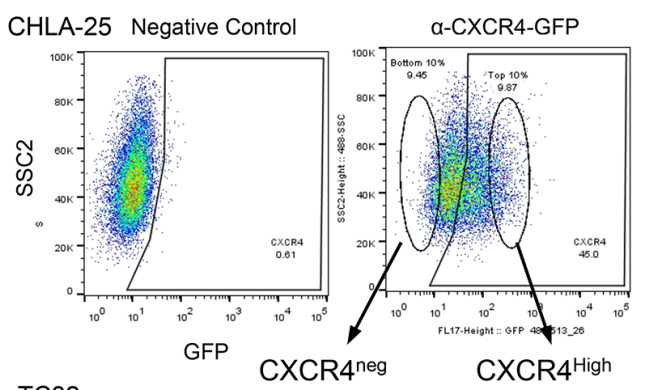

C

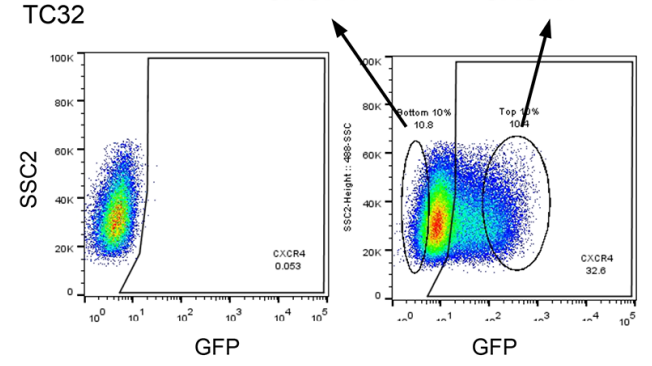

H3K27me3

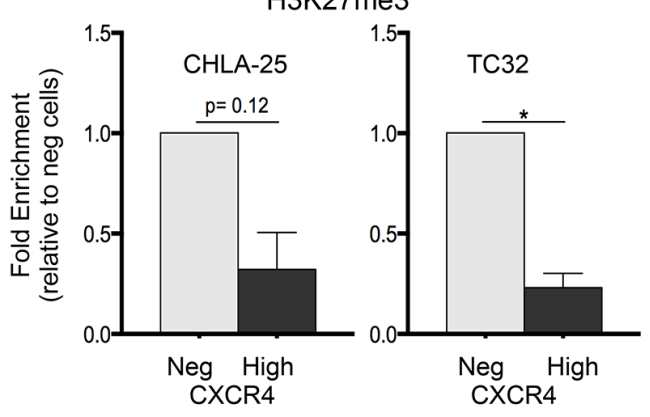

B

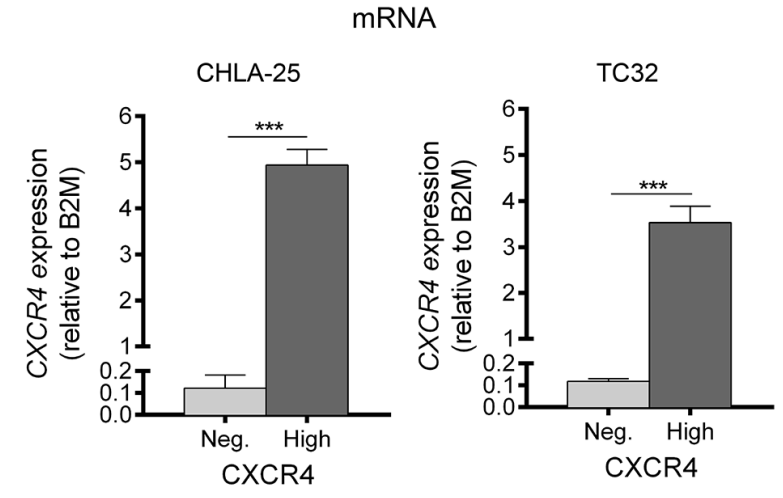

D

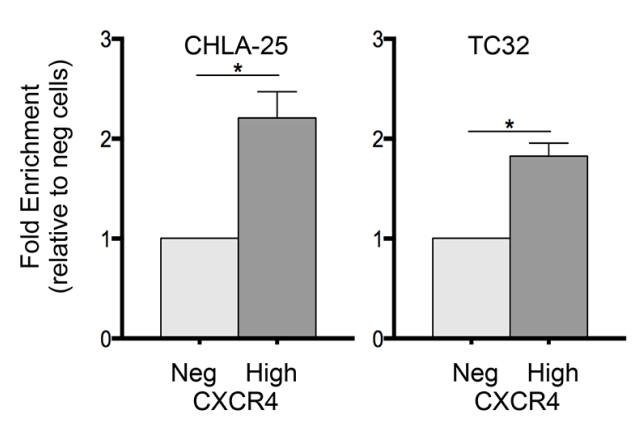

E

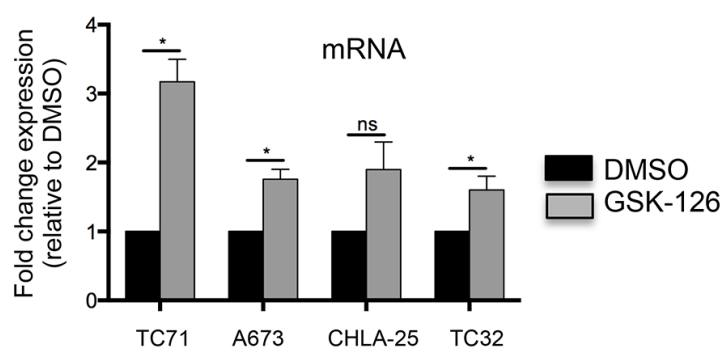

$\mathrm{F}$

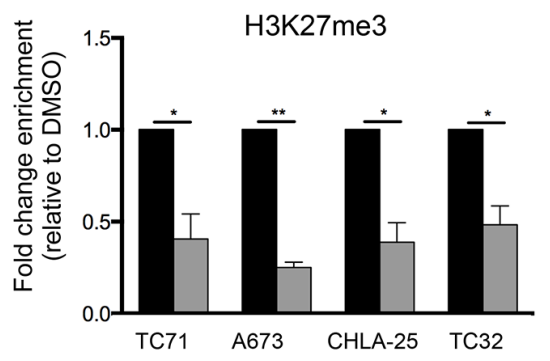

G

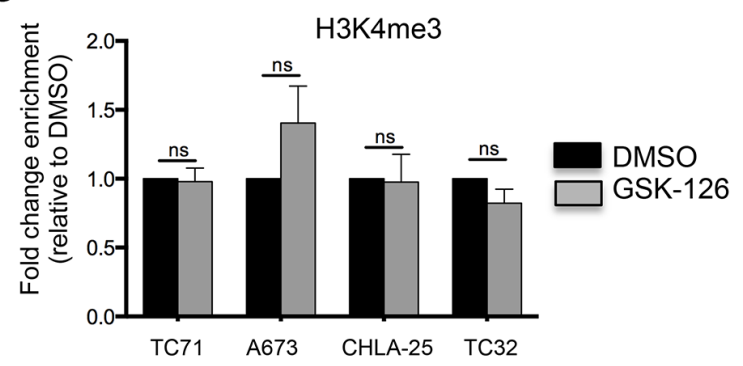

Figure 5: Upregulation of CXCR4 is associated with loss of H3K27me3. A. CHLA-25 and TC32 cells were FACS-sorted into CXCR $^{\text {Neg }}$ (bottom 10\%) and CXCR4 $4^{\text {High }}$ (top 10\%) populations. B. qRT-PCR confirmed that expression of CXCR4 mRNA correlated with CXCR4 surface protein expression in sorted cells. C. ChIP-qPCR experiments revealed that the H3K27me3 modification is relatively reduced in CXCR4 $4_{\text {High }}$ populations compared to CXCR4 ${ }^{\mathrm{Neg}}$ cells. D. In contrast to H3K27me3, the H3K4me3 mark was shown to be increased in CXCR4 $4^{\text {High }}$ populations. E. Exposure of Ewing sarcoma cells to GSK-126 resulted in an increase in CXCR4 expression. F. GSK-126 treated cells showed a loss of H3K27me3 at the CXCR4 promoter G. GSK-126 had no impact on H3K4me3 enrichment. Data represented as mean \pm SEM of three independent experiments. *. $\mathrm{P}<0.05$ as compared to controls. 
in both populations of cells that were subjected to serum withdrawal although the increase in CXCR4 positive cells was not statistically significant (Figure 6E). Concomitant with transcript upregulation, CXCR4 negative cells showed a loss of $\mathrm{H} 3 \mathrm{~K} 27 \mathrm{me} 3$ enrichment at the $C X C R 4$ promoter
(Figure 6F) while enrichment of $\mathrm{H} 3 \mathrm{~K} 4 \mathrm{me} 3$ was unchanged (Figure 6G). No change in either mark was detected in CXCR4 positive cells following serum withdrawal indicating that the increase in transcript was not mediated by a loss of H3K27me3 (Figure 6F \& 6G).
A

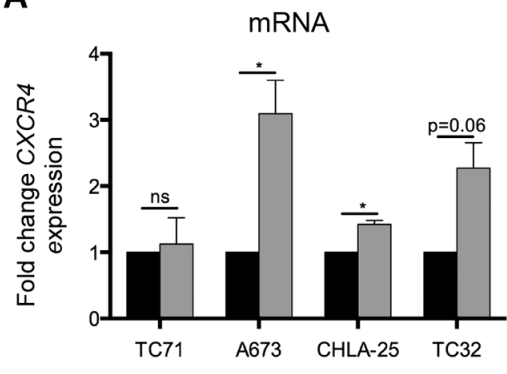

B

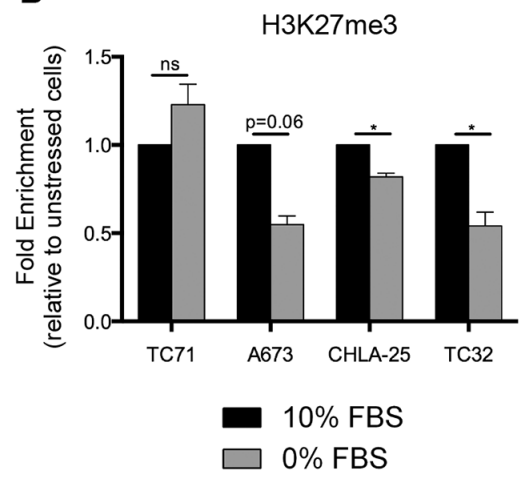

C

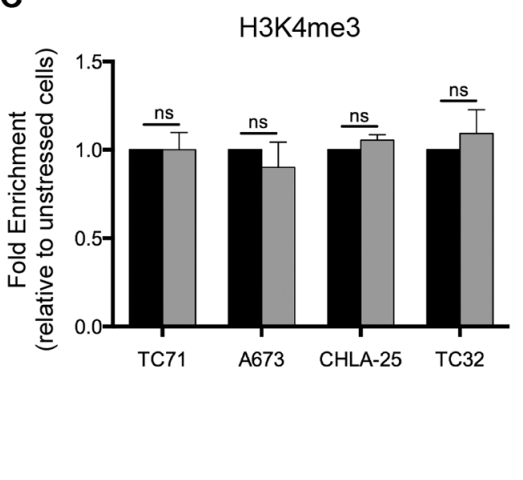

D

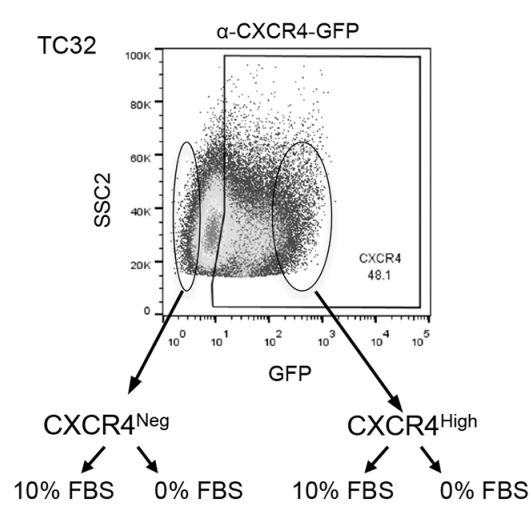

$\mathbf{F}$

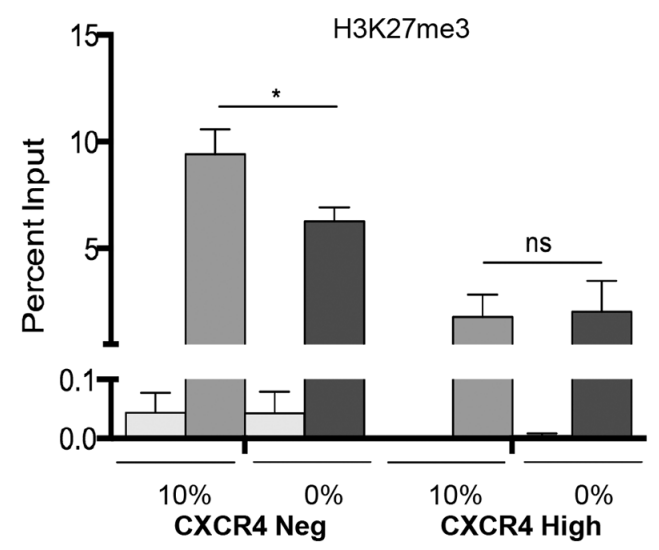

E

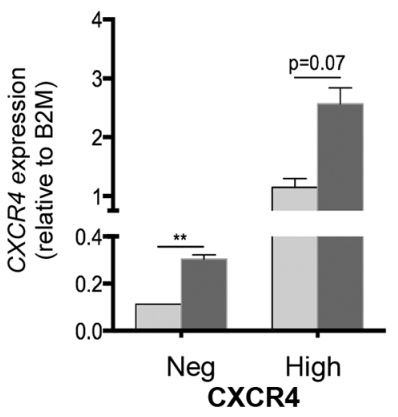

G

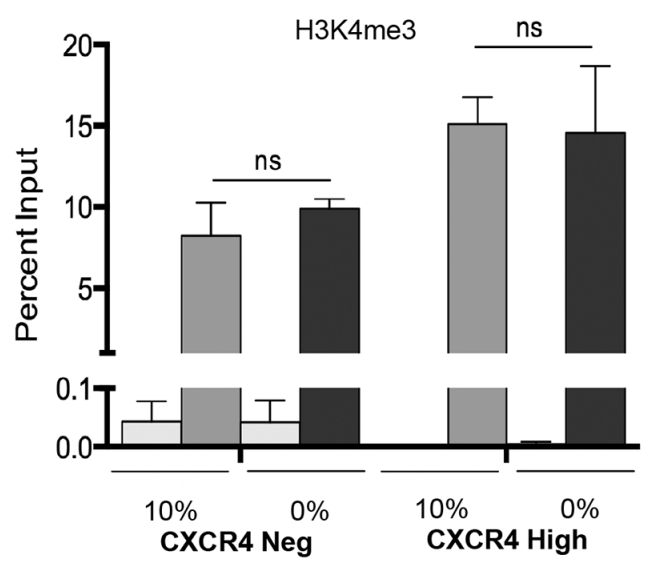

Figure 6: Ewing sarcoma cells lose the repressive H3K27me3 mark at the CXCR4 promoter in response to stress. A. qRT-PCR shows that serum starvation resulted in upregulated expression of CXCR4 expression in three of four Ewing sarcoma cell lines. B. CHIP-qPCR confirmed diminished H3K27me3 enrichment at the CXCR4 promoter in cells with upregulated transcript expression. C. No change in H3K4me3 enrichment was induced by serum deprivation. D. TC32 cells were FACS-sorted to isolate CXCR4 negative cells which were then placed into 10\% FBS or serum deprived conditions for 24 hours. E. CXCR4 mRNA expression was induced by serum deprivation in CXCR4 negative $(\mathrm{p}<0.005)$ and also in CXCR4 positive cells $(\mathrm{p}=0.07) \mathbf{F}$. Loss of H3K27me 3 was evident in CXCR4 negative but not CXCR4 positive cells following serum deprivation. G. Serum withdrawal had no impact on $\mathrm{H} 3 \mathrm{~K} 4 \mathrm{me} 3 \mathrm{enrichment}$ at the CXCR4 promoter in either CXCR4 negative or CXCR4 positive cells. Data are represented as mean $\pm \mathrm{SEM}$ ( $\mathrm{n}=3$ for $C X C R 4$ expression, $\mathrm{n}=2$ or 3 for ChIP experiments). *. $\mathrm{P}<0.05 * * \mathrm{P}<0.005$ as compared to controls. 
NUTRIENT-RICH MICROENVIRONMENT

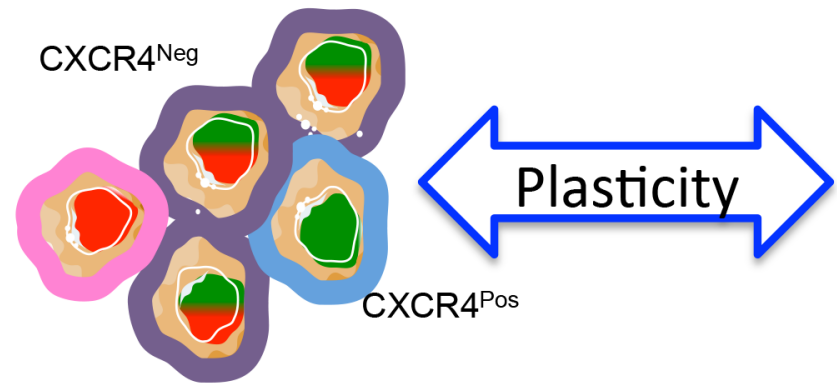

NECROTIC MICROENVIRONMENT

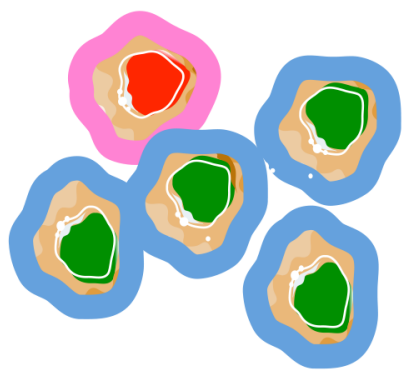

Abundant CXCR4 negative cells Bivalent locus poised for activation
Abundant CXCR4 positive cells

Local growth promotion, metastatic spread?

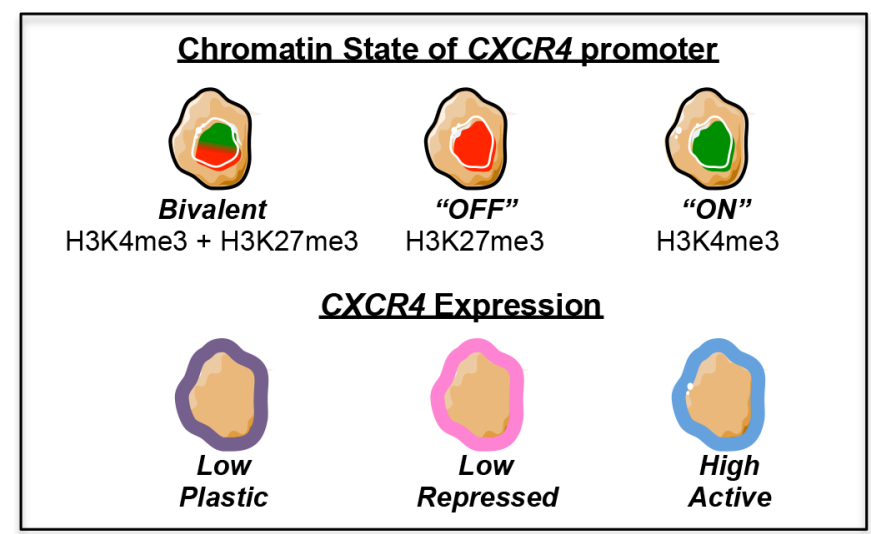

Figure 7: Model of CXCR4 plasticity. Schematic model depicts the potential implications of our results. In this model, stress - such as a necrotic tumor microenvironment - induces CXCR4 negative tumor cells to convert into CXCR4 positive cells, which promote tumor progression via activation of the CXCL12/CXCR4 signaling axis. This conversion is, at least in part, mediated by epigenetic switching of the $C X C R 4$ promoter from an inactive bivalent state to a univalent active state.

Thus, these data together reveal that CXCR4 negative Ewing sarcoma cells exist in a bivalent state wherein the CXCR4 promoter is repressed but poised for rapid activation. Exposure of bivalent tumor cells to microenvironmental stress, such as growth factor deprivation, results in loss of bivalency and gene activation, thereby contributing to stress-dependent induction of CXCR4 and phenotypic transition of cells from CXCR4 negative to CXCR4 positive states (Figure 7).

\section{DISCUSSION}

Ewing sarcomas are aggressive bone and soft tissue tumors that are characterized by the presence of pathognomonic chromosomal translocations that most commonly result in creation of an EWS-FLII, or related $E W S-E R G$, oncogenic fusion gene [18]. Deep sequencing studies of primary Ewing sarcoma tumors at the time of diagnosis have shown that recurrent mutations outside of the tumor-defining fusion are infrequent, demonstrating that clonal, genetic heterogeneity is uncommon prior to therapy [19-21]. In contrast, disruptions to the normal epigenome and epigenetic regulatory complexes are prevalent in Ewing sarcoma and have been shown to be central to tumor pathogenesis [16, 22-27]. Moreover, Ewing sarcomas are presumed to arise from mesenchymal and/or neural crest stem or progenitor cells which by nature are epigenetically plastic $[2,28]$. Thus, it is likely that epigenetic plasticity plays a key role in mediating Ewing sarcoma tumor cell heterogeneity.

Phenotypic heterogeneity among Ewing sarcoma tumor cells has, to date, been relatively understudied. The characteristic small, round, blue cell histology of these tumors is most commonly associated with a very homogeneous cellular morphology, uniform membranous expression of CD99, and an absence of differentiation markers [29]. In addition, clinical standard of care provides only very small needle biopsies prior to the initiation of neoadjuvant chemotherapy, making robust studies of heterogeneity in large tumor resections impossible [30, 31]. Thus most studies of cellular heterogeneity in Ewing sarcoma have, to date, focused on defining inter-tumoral differences in oncogenic fusion type, secondary genetic alterations, gene expression profiles, and clinical behavior $[18-21,30,32,33]$. Nevertheless, a number of studies of 
both primary tumor specimens and Ewing sarcoma cell lines have shown that substantial phenotypic heterogeneity exists among individual tumor cells and direct and indirect evidence from these studies supports the conclusion that this heterogeneity contributes to differences in tumorigenicity, progression, metastatic potential, and treatment response [34-37].

In the current study, we confirmed that Ewing sarcoma cells convert between CXCR4 negative and CXCR4 positive states in vivo. In addition, we observed that CXCR4 negative cells had a propensity to generate CXCR4 positive cells adjacent to areas of tumor necrosis. Thus, these data support our prior in vitro data that CXCR4 negative cells can be converted into CXCR4 positive states cells in response to microenvironmental stress [9]. In addition, we detected a direct correlation between tumor size and $C X C R 4$ expression at the time of necropsy. This finding could indicate that rapidly growing tumors upregulate $C X C R 4$ as they outstrip their blood supply. Alternatively, the positive correlation between CXCR4 expression and tumor size might be due to the direct impact of CXCR4 signaling on tumor growth. Indeed, a prior study showed that CXCL12 promotes the proliferation of CXCR4 positive Ewing sarcoma cells in vitro and the same study also identified a positive correlation between tumor volume and the presence of CXCR4 positive tumor cells in primary human tumors [11]. Thus, CXCR4 positive tumor cells are likely to play a fundamental role in local progression of Ewing sarcoma. Whether or not these cells also contribute to tumor metastasis remains to be determined. Our finding that rates of engraftment are equivalent, in a tail vein model, between CXCR4 negative and CXCR4 positive cells will be informative for future studies of CXCR4 function in models that can evaluate other downstream steps in the metastatic cascade.

From a mechanistic perspective, we found that phenotypic heterogeneity of CXCR4 in Ewing sarcoma tumor cells is, in part, epigenetically mediated. The CXCR4 promoter of CXCR4 negative cells exists in a bivalent state under ambient conditions, characteristic of a transcriptionally silent locus that is poised for activation [13]. When CXCR4 negative Ewing sarcoma cells are deprived of growth factors they upregulate CXCR4 transcript expression and we observed that this is associated with loss of the repressive $\mathrm{H} 3 \mathrm{~K} 27 \mathrm{me} 3$ modification and retention of the activating $\mathrm{H} 3 \mathrm{~K} 4 \mathrm{~m} 3$ modification. In addition, pharmacologic inhibition of $\mathrm{EZH} 2$ leads to increased expression of $C X C R 4$ and loss of $\mathrm{H} 3 \mathrm{~K} 27 \mathrm{me} 3$, providing further evidence that this epigenetic modification contributes to transcriptional repression of the locus in non-stressed conditions. High levels of EZH2 in Ewing sarcoma cells contribute to maintenance of the tumorigenic state and this is mediated, at least in part, by EZH2-mediated repression of cell differentiation [16, 27]. Thus, EZH2 inhibition has been discussed as a potential therapeutic target. However, given our current findings, it will be important to consider that use of EZH2 inhibitors as anti-cancer agents in Ewing sarcoma could have the on-target, but undesirable, effect of activating CXCR4. Further investigation into the potential negative impact of CXCR4 activation on tumor progression is warranted in preclinical studies of EZH2-inhibition.

Studies of breast cancer recently demonstrated the importance of promoter bivalency to phenotypic plasticity and tumor cell heterogeneity [14]. In particular, Chaffer et $a l$. showed that, in sub-populations of breast cancer cells, the promoter of ZEB1, a master regulator of epithelial-tomesenchymal transition, is maintained in an inactive, bivalent state and that loss of bivalency in these cells is induced in response to TGF $\beta$ [14]. Importantly, the bivalent state of the $Z E B 1$ promoter defined cell populations that were able to convert from non-cancer stem cell to cancer stem cell states as a result of their ability to resolve the ZEB1 locus into an activate chromatin configuration [14]. In contrast, non-cancer stem cells whose ZEB1 promoter existed in a univalent, $\mathrm{H} 3 \mathrm{~K} 27 \mathrm{me} 3$ marked state were unable to activate either ZEB1 transcription or a cancer stem cell phenotype in response to TGF $\beta$ [14]. Thus, promoter bivalency was shown to be a key mediator of cell plasticity and the breast cancer stem cell phenotype. These data, combined with our own, now raise the intriguing possibility that bivalency of the $C X C R 4$ locus may be an important factor that contributes to the conversion of CXCR4 negative breast cancer stem cells into CXCR4 positive metastasis-inducing breast cancer stem cell populations [38]. The contribution of epigenetic plasticity to CXCR4 heterogeneity is now worthy of investigation in the context of other tumors that display stem cell characteristics and in which CXCR4 positive cells contribute to tumor progression.

Finally, it is clear from the current work, and from our prior studies, that not all Ewing sarcoma cells uniformly upregulate CXCR4 in response to stress. Some tumor cell lines, such as TC-32 and CHLA-25, are highly plastic and responsive to stress, whereas others, such as TC71, are generally unresponsive. TC71 cells did not activate $C X C R 4$ transcription under conditions of serum deprivation. Nevertheless, exposure of TC71 cells to a potent pharmacologic inhibitor of $\mathrm{EZH} 2$ did result in gene activation concomitant with loss of H3K27me3 and ChIP studies confirmed promoter bivalency. Thus, the bivalent state of the CXCR4 promoter in TC71 cells contributes to gene silencing and is retained under conditions of serum deprivation. Studies of DNA methylation failed to identify differences in promoter DNA methylation among the different cell lines (not shown), supporting the conclusion that other, as yet unknown mechanisms, contribute to $C X C R 4$ repression in TC71 cells. Given what is known about the complexity of CXCR4 regulation, from transcriptional to post-transcriptional mechanisms, translational to post-translational modifications, and the active process of sub-cellular trafficking [39, 40], it is 
highly likely that multiple mechanisms contribute to dynamic regulation of CXCR4 in Ewing sarcoma. Our own observation that CXCR4 positive TC-32 cells further upregulate $C X C R 4$ expression upon serum withdrawal demonstrates that loss of promoter bivalency is not the sole mechanism driving stress-dependent activation. In addition, recent identification of $C X C R 4$ splice variants in Ewing sarcoma tumors and cell lines raises the possibility that alternate promoter usage and altered post-transcriptional regulation might also contribute to dynamic regulation and expression of CXCR4 [41]. Further studies are needed to fully elucidate which of these many mechanisms are activated in response to different microenvironmental cues and how they contribute to tumor progression.

Tumor heterogeneity continues to be a major impediment to cancer cures. In the context of Ewing sarcoma, epigenetic plasticity is likely to play a major role in mediating this heterogeneity and promoting disease progression. Continued elucidation of the mechanisms by which Ewing sarcoma cells alter their phenotypes to adopt more aggressive states is warranted so that novel approaches to therapy can be developed that specifically target and inhibit these heterogeneity-inducing processes.

\section{MATERIALS AND METHODS}

\section{Cell lines}

Ewing sarcoma cell lines were cultured in RPMI1640 media (Gibco, Grand Island, NY, USA) supplemented with 10\% FBS (Atlas Biologicals, Inc., Fort Collins, CO, USA) and $6 \mathrm{mM}$ L-glutamine (Life Technologies, Grand Island, NY, USA) at $37^{\circ} \mathrm{C}$ and $5 \% \mathrm{CO}_{2}$. For CHLA-25 cells, prior to cell seeding, plates were briefly coated $(\sim 5$ minutes) with $0.2 \%$ Gelatin (Gelatin from bovine skin, Type B). For serum starvation conditions, cells were cultured as above without the presence of FBS for 24 hours. For hypoxia studies, cells were incubated inan xVivo system (Biospherix, Lacona, NY, USA) at $1 \% \mathrm{O}_{2}, 37^{\circ} \mathrm{C}$ and $5 \%$ $\mathrm{CO}_{2}$ for 48 hours. For GSK-126 studies, cells were treated with either vehicle control (DMSO; D128-500, Fisher Scientific, Waltham, MA) or 10 $\mu$ M GSK-126 (A-1275, Active Biochem, Maplewood, NJ) daily for 72 hours prior to functional studies.

\section{Immunohistochemistry}

Immunohistochemistry for CXCR4 and CD99 was performed on formalin fixed paraffin embedded tumor sections using the Dako Autostainer Link (Dako, Carpinteria, CA). Following rehydration, sections were treated with heat induced epitope retrieval (HIER). For CXCR4 HIER was performed with FLEX TRS Low pH Retrieval buffer ( $\mathrm{pH}$ 6.10) (Dako) for 20 minutes. For CD99 HIER was performed with FLEX TRS High pH Retrieval buffer (pH 9.01) (Dako) for 20 minutes. After peroxidase blocking, CXCR4 antibody (ab124824; abcam,
Cambridge, MA) was applied at a dilution of 1:4000 at room temperature for 60 minutes, and CD99 antibody (M3601; Dako, Carpinteria, CA) was applied at a dilution of 1:100 at room temperature for 60 minutes. The FLEX HRP EnVision System (Dako) was used for detection. DAB chromagen was then applied for 10 minutes. Slides were counterstained with Harris Hematoxylin for 5 seconds and then dehydrated and coverslipped.

\section{Quantitative real-time PCR}

RNA was isolated using the Quick-RNATM MiniPrep kit (Zymo Research, Irvine, CA) and cDNA was generated using iScript (Bio-Rad, Hercules, CA). Quantitative real-time PCR was performed using validated CXCR4 and beta-2-microglobulin (B2M) Taqman assays (Life Technologies, Grand Island, NY). Analysis was performed in triplicate using the Lightcycler ${ }^{\circledR} 480$ System. Using the $\Delta \Delta \mathrm{Ct}$ method, gene expression was normalized to the reference gene.

\section{Chromatin immunoprecipitation (ChIP)}

Chromatin immunoprecipitation was performed according to the methods of Gilfillan et al. 2012 [42]. In brief, Ewing sarcoma cells $\left(3.6 \times 10^{5}\right.$ per IP) were digested with Micrococcal nuclease (MNase) (70196Y, Affymetrix, Santa Clara, CA) for 5 minutes at $37^{\circ} \mathrm{C}$, sonicated for 20 seconds (Qsonica cup horn sonicator (Qsonica Sonicators, Newtown, CT, USA)), blocked for 1 hour with Dynabeads A $+\mathrm{G}$ (10001D and 10003D; Life Technologies, Carlsbad, CA), incubated with $1 \mu \mathrm{g}$ of desired antibody overnight, incubated with Dynabeads $\mathrm{A}+\mathrm{G}$ for 3 hours, washed (5 minute wash; 5 x RIPA buffer, 1 x LiCl buffer, 1 x TE buffer), digested proteins with Proteinase $\mathrm{K}$ for 1 hour at $55^{\circ} \mathrm{C}$ and purified immunoprecipitated DNA according to manufacturer's instructions (Zymo Genomic DNA Clean \& Concentrator, D4011). For ChIP-re-ChIP studies, after the 3 hour incubation with Dynabeads $A+G$, the beads were incubated with dithiothreitol (DTT) (10mM final concentration, 15508-013, Life Technologies, Carlsbad, CA) for 30 minutes at $37^{\circ} \mathrm{C}$. Chromatin was then incubated with the desired second antibody overnight and the protocol continued as above. Primer pairs for the CXCR4 promoter region are listed in Supplementary Table S1. ChIP antibodies were used as per manufacturer's instructions; H3K4me3 Rabbit anti-Human Polyclonal Antibody (49-1005; Life Technologies, Carlsbad, CA), Anti-trimethyl-Histone H3 (Lys27) Antibody (07-449; Millipore, Billerica, MA), normal mouse IgG (sc-2025; Santa Cruz Biotechnology, Dallas, TX), Rabbit IgG (ab37415; Abcam, Cambridge, MA).

\section{Cell sorting}

Cell sorting was performed as previously described [9]. In brief, cells were blocked for 15 minutes at $4^{\circ} \mathrm{C}$ 
with agitation $(0.5 \%$ FBS $)$, incubated with human CXCR4 Alexa Fluor 488 or Alexa Fluor 700 monoclonal antibody (5 uL/ $1.0 \times 10^{6}$ cells) (R\&D Systems, Minneapolis, MN) for 30 minutes at $4^{\circ} \mathrm{C}$ with agitation, passed through a $0.40 \mu \mathrm{m}$ sterile nylon mesh strainer and sorted into $\mathrm{CXCR} 4^{\text {neg }}$ and $\mathrm{CXCR} 4^{\text {high }}$ on a Beckman Coulter MoFlo Astrios.

\section{In vivo xenografts}

GFP/Luciferase tagged TC-32 cells were first sorted by FACS into $\mathrm{CXCR} 4^{\text {neg }}$ and $\mathrm{CXCR} 4^{\text {high }}$ populations and 1 million sorted cells were injected into NOD SCID mice. Bioluminescence imaging of mice was performed on the Perkin Elmer In Vivo IVIS Spectrum Optical Imaging System to assess time to engraftment post-injection (Center for Molecular Imaging Core, University of Michigan). All animal studies were performed in accordance with protocols approved by the University of Michigan Animal Care and Use Committee.

\section{Statistical analysis}

Data are reported as mean $\pm \mathrm{SEM}$ from at least three independent experiments and p-values calculated using ratio paired t-test unless otherwise indicated. P-values of $<0.05$ were considered significant.

\section{ACKNOWLEDGMENTS}

The authors would like to thank members of the Lawlor laboratory, Dr. Gary Luker, Dr. Maria Castro, Dr. Maria Figueroa and her laboratory, FACs core and Imaging core staff, and Tina Fields for their advice and technical assistance. We also gratefully acknowledge the Department of Radiology at The University of Michigan for the use of The Center for Molecular Imaging and the Tumor Imaging Core.

\section{CONFLICTS OF INTEREST}

The authors have no conflicts of interest to disclose.

\section{GRANT SUPPORT}

The work was supported by grants from the NIH: SARC SPORE 1U01-CA114757, 5T32-CA009676, and through the University of Michigan's Cancer Center Support Grant (P30 CA046592) by the use of the following Cancer Center Core(s): Flow cytometry, Sequencing, and Tumor Imaging Core. Additional financial support from the Evan Shapiro Fund to Combat Pediatric Cancer and the Sarcoma Research Fund of the University of Michigan Comprehensive Cancer Center is gratefully acknowledged.

\section{REFERENCES}

1. Navin N, Krasnitz A, Rodgers L, Cook K, Meth J, Kendall J, Riggs M, Eberling Y, Troge J, Grubor V, Levy D, Lundin P, Maner S, Zetterberg A, Hicks J and Wigler M. Inferring tumor progression from genomic heterogeneity. Genome research. 2010; 20:68-80.

2. Meacham CE and Morrison SJ. Tumour heterogeneity and cancer cell plasticity. Nature. 2013; 501:328-337.

3. Diaz-Cano SJ. Tumor heterogeneity: mechanisms and bases for a reliable application of molecular marker design. International journal of molecular sciences. 2012; 13:1951-2011.

4. Junttila MR and de Sauvage FJ. Influence of tumour microenvironment heterogeneity on therapeutic response. Nature. 2013; 501:346-354.

5. Gassmann P, Haier J, Schluter K, Domikowsky B, Wendel C, Wiesner U, Kubitza R, Engers R, Schneider SW, Homey $\mathrm{B}$ and Muller A. CXCR4 regulates the early extravasation of metastatic tumor cells in vivo. Neoplasia. 2009; 11:651-661.

6. Sun X, Cheng G, Hao M, Zheng J, Zhou X, Zhang J, Taichman RS, Pienta KJ and Wang J. CXCL12 / CXCR4 / CXCR7 chemokine axis and cancer progression. Cancer metastasis reviews. 2010; 29:709-722.

7. Domanska UM, Kruizinga RC, Nagengast WB, TimmerBosscha H, Huls G, de Vries EG and Walenkamp AM. A review on CXCR4/CXCL12 axis in oncology: no place to hide. European journal of cancer. 2013; 49:219-230.

8. Duda DG, Kozin SV, Kirkpatrick ND, Xu L, Fukumura D and Jain RK. CXCL12 (SDF1alpha)-CXCR4/CXCR7 pathway inhibition: an emerging sensitizer for anticancer therapies? Clinical cancer research. 2011; 17:2074-2080.

9. Krook MA, Nicholls LA, Scannell CA, Chugh R, Thomas DG and Lawlor ER. Stress-induced CXCR4 promotes migration and invasion of ewing sarcoma. Molecular cancer research. 2014; 12:953-964.

10. Bennani-Baiti IM, Cooper A, Lawlor ER, Kauer M, Ban $\mathrm{J}$, Aryee DN and Kovar H. Intercohort gene expression co-analysis reveals chemokine receptors as prognostic indicators in Ewing's sarcoma. Clinical cancer research. 2010; 16:3769-3778.

11. Berghuis D, Schilham MW, Santos SJ, Savola S, Knowles HJ, Dirksen U, Schaefer KL, Vakkila J, Hogendoorn PC and Lankester AC. The CXCR4-CXCL12 axis in Ewing sarcoma: promotion of tumor growth rather than metastatic disease. Clinical sarcoma research. 2012; 2:24.

12. Lawlor ER and Thiele CJ. Epigenetic changes in pediatric solid tumors: promising new targets. Clinical cancer research. 2012; 18:2768-2779.

13. Bernstein BE, Mikkelsen TS, Xie X, Kamal M, Huebert DJ, Cuff J, Fry B, Meissner A, Wernig M, Plath K, Jaenisch R, Wagschal A, Feil R, Schreiber SL and Lander ES. A bivalent chromatin structure marks key developmental genes in embryonic stem cells. Cell. 2006; 125:315-326. 
14. Chaffer CL, Marjanovic ND, Lee T, Bell G, Kleer CG, Reinhardt F, D'Alessio AC, Young RA and Weinberg RA. Poised chromatin at the ZEB1 promoter enables breast cancer cell plasticity and enhances tumorigenicity. Cell. 2013; 154:61-74.

15. Consortium EP. An integrated encyclopedia of DNA elements in the human genome. Nature. 2012; 489:57-74.

16. Richter GH, Plehm S, Fasan A, Rossler S, Unland R, Bennani-Baiti IM, Hotfilder M, Lowel D, von Luettichau I, Mossbrugger I, Quintanilla-Martinez L, Kovar H, Staege MS, Muller-Tidow C and Burdach S. EZH2 is a mediator of EWS/FLI1 driven tumor growth and metastasis blocking endothelial and neuro-ectodermal differentiation. Proc Natl Acad Sci U S A. 2009; 106:5324-5329.

17. McCabe MT, Ott HM, Ganji G, Korenchuk S, Thompson C, Van Aller GS, Liu Y, Graves AP, Della Pietra A, 3rd, Diaz E, LaFrance LV, Mellinger M, Duquenne C, Tian X, Kruger $\mathrm{RG}, \mathrm{McHugh} \mathrm{CF}$, et al. EZH2 inhibition as a therapeutic strategy for lymphoma with EZH2-activating mutations. Nature. 2012; 492:108-112.

18. Lawlor ER and Sorensen PH. Twenty Years on: What Do We Really Know about Ewing Sarcoma and What Is the Path Forward? Critical reviews in oncogenesis. 2015; 20:155-171.

19. Crompton BD, Stewart C, Taylor-Weiner A, Alexe G, Kurek KC, Calicchio ML, Kiezun A, Carter SL, Shukla SA, Mehta SS, Thorner AR, de Torres C, Lavarino C, Sunol M, McKenna A, Sivachenko A, et al. The genomic landscape of pediatric Ewing sarcoma. Cancer discovery. 2014; 4:1326-1341.

20. Brohl AS, Solomon DA, Chang W, Wang J, Song Y, Sindiri S, Patidar R, Hurd L, Chen L, Shern JF, Liao H, Wen X, Gerard J, Kim JS, Lopez Guerrero JA, Machado I, et al. The Genomic Landscape of the Ewing Sarcoma Family of Tumors Reveals Recurrent STAG2 Mutation. PLoS genetics. 2014; 10:e1004475.

21. Tirode F, Surdez D, Ma X, Parker M, Le Deley MC, Bahrami A, Zhang Z, Lapouble E, Grossetete-Lalami S, Rusch M, Reynaud S, Rio-Frio T, Hedlund E, Wu G, Chen $\mathrm{X}$, Pierron G, et al. Genomic landscape of Ewing sarcoma defines an aggressive subtype with co-association of STAG2 and TP53 mutations. Cancer discovery. 2014; 4:1342-1353.

22. Tomazou EM, Sheffield NC, Schmidl C, Schuster M, Schonegger A, Datlinger P, Kubicek S, Bock C and Kovar H. Epigenome mapping reveals distinct modes of gene regulation and widespread enhancer reprogramming by the oncogenic fusion protein EWS-FLI1. Cell reports. 2015; 10:1082-1095.

23. Svoboda LK, Harris A, Bailey NJ, Schwentner R, Tomazou E, von Levetzow C, Magnuson B, Ljungman M, Kovar H and Lawlor ER. Overexpression of HOX genes is prevalent in Ewing sarcoma and is associated with altered epigenetic regulation of developmental transcription programs. Epigenetics. 2014; 9:1613-1625.

24. Sankar S, Theisen ER, Bearss J, Mulvihill T, Hoffman LM, Sorna V, Beckerle MC, Sharma S and Lessnick SL. Reversible LSD1 inhibition interferes with global EWS/ETS transcriptional activity and impedes Ewing sarcoma tumor growth. Clinical cancer research. 2014; 20:4584-4597.

25. Riggi N, Knoechel B, Gillespie SM, Rheinbay E, Boulay G, Suva ML, Rossetti NE, Boonseng WE, Oksuz O, Cook EB, Formey A, Patel A, Gymrek M, Thapar V, Deshpande V, Ting DT, et al. EWS-FLI1 utilizes divergent chromatin remodeling mechanisms to directly activate or repress enhancer elements in Ewing sarcoma. Cancer cell. 2014; 26:668-681.

26. von Levetzow C, Jiang X, Gwye Y, von Levetzow G, Hung L, Cooper A, Hsu JH and Lawlor ER. Modeling initiation of Ewing sarcoma in human neural crest cells. PLoS One. 2011; 6:e19305.

27. Riggi N, Suva ML, Suva D, Cironi L, Provero P, Tercier S, Joseph JM, Stehle JC, Baumer K, Kindler V and Stamenkovic I. EWS-FLI-1 expression triggers a Ewing's sarcoma initiation program in primary human mesenchymal stem cells. Cancer Res. 2008; 68:2176-2185.

28. Meltzer PS. Is Ewing's sarcoma a stem cell tumor? Cell Stem Cell. 2007; 1:13-15.

29. Khoury JD. Ewing sarcoma family of tumors. Adv Anat Pathol. 2005; 12:212-220.

30. Shukla N, Schiffman J, Reed D, Davis IJ, Womer RB, Lessnick SL, Lawlor ER and Committee COGESB. Biomarkers in Ewing Sarcoma: The Promise and Challenge of Personalized Medicine. A Report from the Children's Oncology Group. Frontiers in oncology. 2013; 3:141.

31. Borinstein SC, Beeler N, Block JJ, Gorlick R, Grohar P, Jedlicka P, Krailo M, Morris C, Phillips S, Siegal GP, Lawlor ER, Lessnick SL and Committee COGESB. A Decade in Banking Ewing Sarcoma: A Report from the Children's Oncology Group. Frontiers in oncology. 2013; 3:57.

32. Volchenboum SL, Andrade J, Huang L, Barkauskas DA, Krailo M, Womer RB, Ranft A, Potratz J, Dirksen U, Triche TJ and Lawlor ER. Gene Expression Profiling of Ewing Sarcoma Tumors Reveals the Prognostic Importance of Tumor-Stromal Interactions: A Report from the Children's Oncology Group. The journal of pathology Clinical research. 2015; 1:83-94.

33. van Doorninck JA, Ji L, Schaub B, Shimada H, Wing MR, Krailo MD, Lessnick SL, Marina N, Triche TJ, Sposto R, Womer RB and Lawlor ER. Current treatment protocols have eliminated the prognostic advantage of type 1 fusions in Ewing sarcoma: a report from the Children's Oncology Group. Journal of clinical oncology. 2010; 28:1989-1994.

34. De Vito C, Riggi N, Cornaz S, Suva ML, Baumer K, Provero $\mathrm{P}$ and Stamenkovic I. A TARBP2-dependent miRNA expression profile underlies cancer stem cell properties and provides candidate therapeutic reagents in Ewing sarcoma. Cancer cell. 2012; 21:807-821.

35. Suva ML, Riggi N, Stehle JC, Baumer K, Tercier S, Joseph JM, Suva D, Clement V, Provero P, Cironi L, Osterheld $\mathrm{MC}$, Guillou L and Stamenkovic I. Identification of cancer stem cells in Ewing's sarcoma. Cancer Res. 2009; 69:1776-1781. 
36. Wiles ET, Bell R, Thomas D, Beckerle M and Lessnick SL. ZEB2 Represses the Epithelial Phenotype and Facilitates Metastasis in Ewing Sarcoma. Genes Cancer. 2013; 4:486500. doi: 10.1177/1947601913506115.

37. Anderson JL, Titz B, Akiyama R, Komisopoulou E, Park A, Tap WD, Graeber TG and Denny CT. Phosphoproteomic profiling reveals IL6-mediated paracrine signaling within the Ewing sarcoma family of tumors. Molecular cancer research. 2014; 12:1740-1754.

38. Mukherjee S, Manna A, Bhattacharjee P, Mazumdar M, Saha S, Chakraborty S, Guha D, Adhikary A, Jana D, Gorain M, Mukherjee SA, Kundu GC, Sarkar DK and Das T. Non-migratory tumorigenic intrinsic cancer stem cells ensure breast cancer metastasis by generation of CXCR4 migrating cancer stem cells. Oncogene. 2016.
39. Marchese A. Endocytic trafficking of chemokine receptors. Current opinion in cell biology. 2014; 27:72-77.

40. Busillo JM and Benovic JL. Regulation of CXCR4 signaling. Biochimica et biophysica acta. 2007; 1768:952-963.

41. Sand LG, Scotlandi K, Berghuis D, Snaar-Jagalska BE, Picci P, Schmidt T, Szuhai K and Hogendoorn PC. CXCL14, CXCR7 expression and CXCR4 splice variant ratio associate with survival and metastases in Ewing sarcoma patients. European journal of cancer. 2015; 51:2624-2633.

42. Gilfillan GD, Hughes T, Sheng Y, Hjorthaug HS, Straub T, Gervin K, Harris JR, Undlien DE and Lyle R. Limitations and possibilities of low cell number ChIP-seq. BMC genomics. 2012; 13:645. 